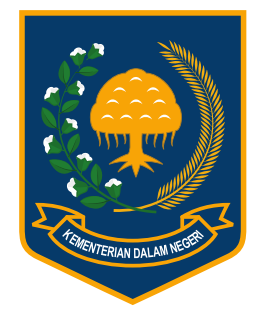

Jurnal Bina Praja 8 (1) (2016): 135-148

Jurnal Bina Praja

e-ISSN: 2503-3360 | p-ISSN: 2085-4323

Accreditation Number

735/AU2/P2MI-LIPI/04/2016

http://jurnal.kemendagri.go.id/index.php/jbp/index

\title{
The Application of Participatory Communication IN THE IMPLEMENTATION of SMall Farmers Empowerment Program
}

\author{
Sitti Aminah ${ }^{1, *}$ \\ ${ }^{1}$ Research and Development Agency, Ministry of Home Affairs (BPP Kemendagri) \\ Jl. Kramat Raya No. 132, Senen, Jakarta Pusat
}

Received: 1 March 2016; Accepted: 10 May 2016; Published online: 31 May 2016

\begin{abstract}
An agricultural development approach that is centralized, top down, and applied linear communication (transfer of technology) puts farmers as a tool to achieve national's goals (rice self-sufficiency) and makes them dependant to the outsiders. This study aims to analyze the level of participatory communication implementation in the implementation of Small Farmers Empowerment Program. The data are collected using some methods: observation, interview and focus group discussion. The data are analyzed using descriptive statistic. The study result shows that the implementation of participatory communication is in a low category. The recommendations of this study are to enhance the ability of small farmers through increasing the intensity of dialogue between the small farmers and the stakeholders (insiders and outsiders). Exchange of information and knowledge through ideal dialogue as the medium of exchange of information and knowledge to cope with problems of farming.
\end{abstract}

Keywords: participatory communication, empowerment, small farmers.

\section{INTRODUCTION}

Communication and participation are key components of successful development. Most development programs in third world countries failed to overcome poverty because of low participation and communication mismatches in the process of empowerment (Servaes 2002; Mefalopulos 2003). Various development programs have less impact on the improvement in the lives of small farmers in rural areas because of factors such as low participation, the program is not targeted because the information is inaccurate, the technology is not appropriate, agricultural information and innovation are poorly understood and applied by farmers because the mismatch of language style, communication channel, and media. Outsiders feel more knowledgeable that they ignore local knowledge and the lack of dialogue in learning and counseling to farmers (Ascroft \& Masilela 2004; Anyaegbunam et al. 2004). The intervention of outsiders and local elites has undermined people participation in the decision-making process (Chambers 1997; Mosse 2004; and Belbase 2004).

The approach to agricultural development, which is carried out in a centralized manner, topdown, and by applying a linear communication (transfer of technology) without the interaction and involvement of farmers in decision-making development, has created helpless farmers (Sumardjo 1999). Farmers who are helpless is the successful condition of failure in agricultural development. One form of the failure of agricultural development is the dependence on food imports (rice, soybeans, sugar, corn, meat and even fish and salt). In North Maluku, the capacity of farmers in producing food crops is low. The low capability among others is influenced by the weakness of the process of empowerment of farmers and farmers' low access to agricultural development input. These conditions led to dependence on food supplies from outside the region. As a result, food prices are expensive and less affordable by the majority of low-income households. It is thought to be one of the causes of the high food-insecure population.

The weakness in the empowerment program implementation is often caused by the thoughts of the organizers of development that often defies logic with great planning vision without dialogue

\footnotetext{
* Corresponding Author

Phone : +6282113160178

Email : sittiaminah.kemendagri@gmail.com
} 
with the people who live off that decision. The development-oriented more on political interests (stability, the status-quo, and power), capital accumulation and economic elite profit (Servaes 2002, 2005, 2006; Mefalopulos 2003). Thus, the adoption of participatory approach and dialogue is very suitable in the process of empowerment of farmers to increase the capacity of farmers (Ascroft \& Masilela 2004; Anyaegbunam et al., 2004; Leeuwis 2009; Cummins \& Conventry 2009). The rationality on the importance of dialogue for the development is because the knowledge of external agents is (government officials, assistants, and expert) although valid but not sufficient in solving local problems. They need to learn and have a dialogue with the people (farmers) who have local knowledge (indigenous intellectual) (White, 2004; Cummins \& Conventry 2009).

Participatory communication is the exchange of information between the parties involved in the development process through dialogue to achieve mutualunderstanding (commonunderstanding) and consensus for the decision-making process. A study on the application of participatory communication in development programs has been done by other researchers: Ketan Chitnis (2011) analyzes the application of participatory communication in a health program called "Comprehensive Rural Health Project (CRHP)" in Jamkhed, India by using the qualitative approach with the constructivist paradigm. The result showed that the application of participatory communication through the sharing of information for mapping joint problem between insider and outsider create collective knowledge and strengthening the changing environment. Imani Satriani (2011) analyzes the application of participatory communication in the Family EmpowermentProgram in Bogor, Indonesia. By using qualitative analysis and constructivist paradigm, it is found that participatory communication applied to the Program of Family Empowerment Post covers the same access to participate in the stages of the program, heteroglossia (equality among fellow participants in the opinion), poliponi (no intervention by certain parties to the decision of the group), the similar dialogue between participants and leaders and carnival (informal situations and familiarity) of activities in the field of health, economy and environment.

This study analyzes the application of the concept of participatory communication, which is a dialogue between insider (local residents, farmers) and outsiders (companion, officer, providers of the program) at this stage of the empowerment program. The concept used is participatory communication as dialogue. To analyze the quality of dialogue with between the farmers with insider and outsider, utilized a concept of Habermas about ideal speech situation. The method used is quantitative and descriptive statistical analysis and reinforced by qualitative analysis.

The research problem posed is: how the level of participatory communication implementation in the empowerment of small farmers and how to improve the application of participatory communication strategies in the empowerment of small farmers? This study aims: first, to analyze the level of implementation of participatory communication in the empowerment of small farmers and second, to formulate a strategy to increase participatory communication in the implementation of the empowerment of small farmers.

According to Servaes and Thomas in Chitnis (2011), participatory communication is a development paradigm that is derived from two intellectual roots ( the root of intellectual). Freire critical approach used in the 1970s in adult literacy programs (adult literacy) in faveals and barrios in Brazil. According to Freire people can be free from oppression if they had the chance to deal with the problem (problem posing) and think critically (critical thinking) on the structural conditions of oppression. Proponents of the theory of communication use this concept as a communicative tool of involvement in the development process. Mc Phail (2009) stated the position of participatory communication is related to the perspectives of development projects in third world countries and its relevance to the concept of Freire.

Some experts have defined participatory communication as dialogue. According to Nair and White (2004), participatory communication as an open dialogue, a source and a receiver that interact continuously, to think about the situation constructively, identify the needs and problems of development, to decide what is needed to improve the situation and act on the situation ("the opening of dialogue, source and receiver interacting continuously, thinking constructively about the situation, identifying developmental needs and problems, Deciding what is needed to improve the situation, and acting upon that"). Singhal (2003) defined participatory communication as a dynamic, interactive and transformational process, where people are engaged in dialogue with individuals and community groups in order to realize their full potential to improve their lives. (Participatory communication is a dynamic, interactive and transformational process, where people are engaged in a dialogue, with individuals and community groups, in order to realize their full potential to be able to improve their lives).

Participatory communication as transactional communication is proposed by Nair and White (2004) which stated that transactional communications as the basis for participatory communication are a 


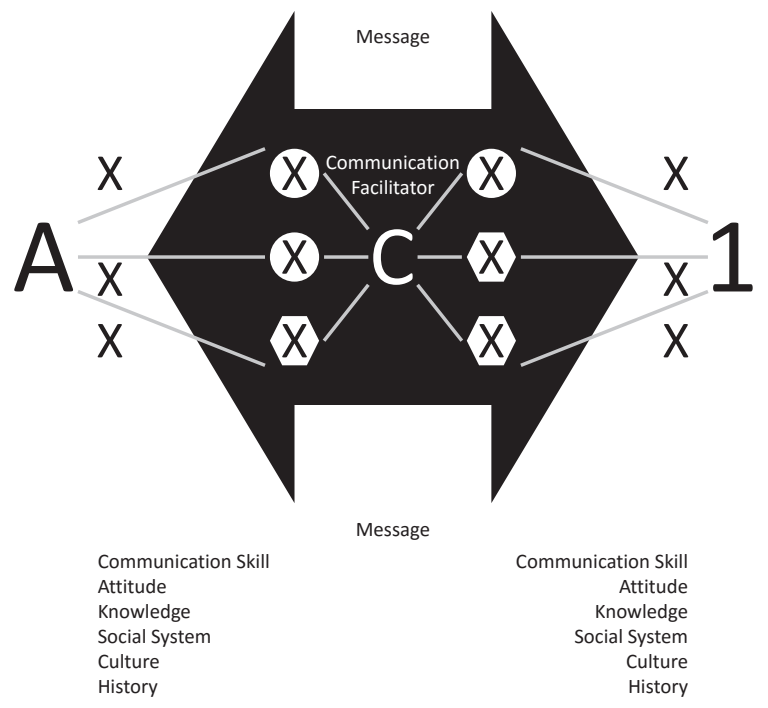

Figure 1. Working Model of Communication for the Convergence of the Interests of Providers and Beneficiaries (Anyaegbunam, 2004) dialogue, in which the sender and receiver interact at the same time to share meanings with balanced and equal force.

Thus, participatory communication is the exchange of information between the parties involved in the development process through dialogue to achieve mutual understanding (common understanding) and consensus for the decisionmaking process. The dialogue becomes a means or basis of communication or information exchange. The essence of dialogue is the recognition and respect and to consider the other participants in the dialogue independent (autonomous subject) and not a communication object. Everyone has an equal right to speak and to listen and to expect their voices not to be oppressed by other voices. Dialogue as a basis of communication in a development program that claims to be participatory means people is exchanging information and cooperating with outsiders (program providers apparatus, facilitators and the local elite) in the decision-making process. The application of participatory communication in small farmer empowerment program refers to the

Table 1.

Paradigm Shift of "Non-participatory Communication" and "Participatory Communication" in Development Program

\begin{tabular}{|c|c|c|}
\hline Elements & $\begin{array}{l}\text { Non-participatory Communication } \\
\text { Implementation }\end{array}$ & $\begin{array}{l}\text { Participatory Communication } \\
\text { Implementation (Dialogue) }\end{array}$ \\
\hline Interactions between actors of program & $\begin{array}{l}\text { - Outsiders are active, beneficiary residents } \\
\text { are passive } \\
\text { - Initiative of outsiders / agent (companion), } \\
\text { residents just execute } \\
\text { - Differentiate the position of agents and } \\
\text { citizens } \\
\text { - Extrinsic motivation is more dominant }\end{array}$ & $\begin{array}{l}\text { - Outsiders and beneficiaries are both active } \\
\text { - Development initiative is from the dialogues } \\
\text { between residents and between residents } \\
\text { and outsiders/development agents. } \\
\text { - Residents act based on their critical aware- } \\
\text { ness of the reality } \\
\text { - Equal principle of agents-residents } \\
\text { - Intrinsic motivation is more dominant }\end{array}$ \\
\hline $\begin{array}{l}\text { Development message } \\
\text { (Program material) }\end{array}$ & $\begin{array}{l}\text { - Program material is determined by the } \\
\text { "above" and one-sided } \\
\text { - Instructive and propagandistic } \\
\text { - Program is not according to needs }\end{array}$ & $\begin{array}{l}\text { - Program material is determined together by } \\
\text { agents and residents } \\
\text { - Interactive, dialogic, and reciprocity } \\
\text { - The program is according to residents' } \\
\text { needs }\end{array}$ \\
\hline Development communication media & $\begin{array}{l}\text { - Media as a channel for delivering messages/ } \\
\text { interests from "above". } \\
\text { - Media as a means of the legitimacy of } \\
\text { decisions that have been established from } \\
\text { "above" }\end{array}$ & $\begin{array}{l}\text { - Media of development as a channel to bring } \\
\text { together the message from "above" and } \\
\text { from "below". } \\
\text { - Media as a public space shuttle between } \\
\text { actors of the program to discuss common } \\
\text { interests }\end{array}$ \\
\hline $\begin{array}{l}\text { Dialogue situations } \\
\text { (residents-residents; residents-agents) }\end{array}$ & $\begin{array}{l}\text { - There is dominance in the communication } \\
\text { process at the community level because of } \\
\text { differences in gender, social and economic } \\
\text { status. } \\
\text { - The dominance of outsiders in the deci- } \\
\text { sion-making. } \\
\text { - Accepting the determination of the decision } \\
\text { of the "above" }\end{array}$ & $\begin{array}{l}\text { - Have equal rights and equal footing and } \\
\text { mutual respect among participants in the } \\
\text { dialogue. } \\
\text { - A decision without the domination of inter- } \\
\text { ests and influence from others. } \\
\text { - Freely express opinions without the pres- } \\
\text { sure of others. } \\
\text { - Argumentative before decisions are made }\end{array}$ \\
\hline Target to the communicant (people) & $\begin{array}{l}\text { - Creating dependency behavior } \\
\text { - People are waiting for instructions } \\
\text { - Apathetic towards the development } \\
\text { dynamics }\end{array}$ & $\begin{array}{l}\text { - Creating a culture of behavior } \\
\text { - The community is initiative, creative, and } \\
\text { innovative. } \\
\text { - Independent and able to adapt }\end{array}$ \\
\hline
\end{tabular}

Source: Conceptual Study Result

The Application of Participatory Communication 
model proposed by Anyaegbunam et al. (2004) as presented in Figure 1.

The opinions of Freire and Habermas about the praxis of dialogue have the same view. Freire emphasizes that the dialogue between beneficiaries and change agents have the same status for the exchange of knowledge. Emphasis on information flows of two or multidirectional has something in common with the specifications of the mutual understanding of communicative action (mutual understanding). Habermas' theory of communicative action states that in talking situations if all actors feel that the structure of speech situation is ideal and the validity claim is open to negotiation, social action is oriented towards mutual understanding, then this theory can provide a theoretical foundation for participation (Jacobson, 2003).

Habermas in Moral Consciousness and Communicative Action stated that the situation of the talks is at a logical level, a situation where the speakers have strong and consistent arguments, namely by eliminating the contradictions that exist in themselves and consistently apply the meaning. At the level of dialectical process, it demands people involved in the discussion on the problematic claim to adopt a hypothetical attitude that can make them consider the validity of the claims regardless of the immediate needs in the situation. While at the level of rhetorical processes, it demands the situation structure of talks to be free from pressure and inequality. At the rhetorical level, Habermas stated that the ideal speech situation in which every actor involved in the dialogue is immune to external or internal restrictions on the communicative structure. (Chang 2007).

Referring to Habermas' theory, the ideal situation for dialogue between outsider and insider is characterized by: (1) Dialogue based on mutual understanding, equal, have the same opportunity to argue, express each purpose, feelings, and attitudes that apply on a reciprocal basis; (2) Dialogue that avoids the interest of subjectivity and free from the domination of others, and (3) Grow validity claims (correctness, accuracy, honesty and comprehensibility), statements with arguments based on data, facts and evidence and is willing to bow to the most rational argument. The application of participatory communication in farmer empowerment program is aimed at ensuring that farmers are not just passive program recipients but have greater control and power over decisions that affect them. Differences in communication paradigm of participatory and non-participatory communications in empowerment programs are presented in Table 1.

Small farmer or known as Peasant, Wolf (1985) defined peasant as someone who works to make ends meet from agricultural activities, either in the form of agricultural business in the field of food crops, horticulture, agriculture, livestock and fisheries. The characteristics of small farmers are: (i) the low level of education, according to the data of BPS (2008), the average length of education of farmers' ranges between 0-6 years, (ii) narrow land ownership, which means landless or have under 0.5 hectares of land, and (iii) low income and access to the means of production, capital, and markets. The empowerment program of small farmers carried out in North Maluku is Smallholder Livelihood Development Programme in Eastern Indonesia (SOLID) as the cooperation between Indonesian government (Ministry of Agriculture) and the International Fund for Agricultural Development (IFAD), which aims to achieve farmers' household food security categorized as poor in dryland village for the period of 2012-2018.

\section{METHOD}

The study evaluates the level of participatory communication implementation at the stage of the growth of the idea, planning, implementation, monitoring and program evaluation and assesses the ideal situation of dialogue that is equality, independence, open debate, and arguments in the implementation of the Small Farmer Empowerment Program. Survey method is used with quantitative paradigm as a tool of analysis and complemented with information based on qualitative data to supplement the quantitative analysis.

The determination of research locations is purposive, namely four villages in the sub-districts of Jailolo and East Sahu in West Halmahera which organize the Small Farmer Income Improvement Program (Small holder Lifelihood Program-SOLID), namely Bukumatiti, Todowongi, Tuada, and Taba Cempaka. The reasons for choosing those four villages as research locations are because (i) other than as the location of empowerment of small farmers, the four villages also experience resource degradation due to shifting agriculture, poverty, and food insecurity are (ii) those are former conflicted areas which impacts are directly felt by the residents which majority are farmers.

The research sample is divided into two strata, i.e. Strata I is farmers with land ownership $\leq 20000$ square meters and Strata II is farmers with land ownership > 20000 square meters. The total number of population in the four villages is 790 households. Of the total population of samples, taken as many as 202 farmers in four villages in the research location. The number of samples from Strata I farmers' category is 162 people and the number of Strata II farmers' category is 40 people. Farmers in a layer of Strata II are small farmers participating in the empowerment program of small farmers in the research location. The population and sample of 
Tabel 2.

Sample of Study Based on Population and Sample

\begin{tabular}{|c|c|c|c|c|c|c|c|}
\hline No. & $\begin{array}{l}\text { Sub-district/ } \\
\text { Village }\end{array}$ & $\begin{array}{l}\text { Number of } \\
\text { Population } \\
\text { per Village }\end{array}$ & $\begin{array}{c}\text { Number of } \\
\text { Population } \\
\text { per Strata }\end{array}$ & & $\begin{array}{l}\text { Number of } \\
\text { Sample per } \\
\text { Strata }\end{array}$ & & $\begin{array}{l}\text { Total of } \\
\text { Sample }\end{array}$ \\
\hline & & & 1 & II & I & II & \\
\hline 1 & $\begin{array}{l}\text { Jailolo } \\
\text { Sub-district }\end{array}$ & 180 & 120 & 60 & 40 & 10 & 50 \\
\hline 1 & Tuada Village & 211 & 160 & 51 & 40 & 10 & 50 \\
\hline 2 & $\begin{array}{l}\text { Todowongi } \\
\text { Village }\end{array}$ & 283 & 213 & 70 & 42 & 10 & 52 \\
\hline II & $\begin{array}{l}\text { Sahu Timur } \\
\text { Sub-district }\end{array}$ & & & & & & \\
\hline 1 & $\begin{array}{l}\text { Taba Campaka } \\
\text { Village }\end{array}$ & 116 & 75 & 31 & 40 & 10 & 50 \\
\hline & TOTAL & 790 & 568 & 222 & 162 & 40 & 202 \\
\hline
\end{tabular}

study are presented in Table 2.

The primary data collection uses a questionnaire that meets the requirements of validity and reliability. Based on validity test of SPSS version 19, it is known that the instrument of research is proved valid with a validity coefficient values ranged between $0.427-0.973$, which means that the instrument is reliable for measuring variables. To test the reliability of the questionnaire, used the formula of Cronbach's Alpha (Kountur 2006):

$$
\alpha=\left(\frac{N}{N-1}\right)\left(\frac{\sum \sigma^{2} \text { item }}{\sigma^{2} \text { total }}\right)
$$

Remarks:

$$
\begin{array}{ll}
\alpha & =\text { Cronbach's Alpha } \\
\mathrm{N} & =\text { Number of questions } \\
{ }^{{ }^{2}} \text { item } & =\text { Variance of questions } \\
{ }^{\sigma_{2}} \text { total } & =\text { Variance of score }
\end{array}
$$

Measurement is made based on alpha Cronbach's scale of 0 to 1 . If the scale of it is grouped into five classes with the same range, then the alpha equilibrium measure can be interpreted as follows:

1. The value of alpha Cronbach of 0.00 to 0.20 , means less reliable

2. The value of alpha Cronbach of 0.21 to 0.40 , means rather reliable

3. The value of alpha Cronbach of 0.42 to 0.60 , means quite reliable

4. The value of alpha Cronbach of 0.61 to 0.80 , means reliable

5. The value of alpha Cronbach of 0.81 to 1.00 , mean strongly reliable

Based on the result of instrument reliability analysis using SPSS 19, it is known that the instrument prepared for research purposes is reliable. This is evidenced by the value of reliability (Cronbach's alpha) ranging from 0.846 to 0.877 . To complement the quantitative data of data collection, conducted interviews and FGD with formal and informal leaders in the village as well as government officials.

For the purposes of statistical testing, the transformation is conducted so that all collected data have the same range, which is $0-100$. Referring to Sumardjo (1999), the guideline for transformation can be done by determining the smallest index value given to the lowest score and a score of 100 for the highest score of each indicator. This kind of transformation is used to calculate the value of diversity that occurs in this study variables, especially the one with ordinal scale into an interval or ratio so it is proper to be tested using parametric statistics.

The general formula of transformation used in this study is as follows:

1) Transformation of Indicators Index:

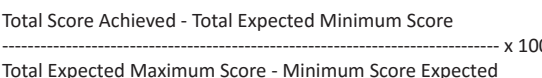

\section{2) Transformation of Variables Index}

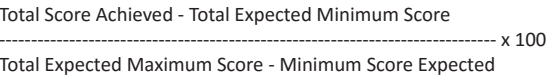

Remarks: interval of variable index values 0 - 100

In this study, the measurement of indicators uses 1-4 scale parameter, so that the minimum transformation index value (0) is achieved when all the parameters of each indicator measured are in 
the value of 1 . The maximum value (100) is when all the parameters of each indicator are in the value of 4 , so the distribution of the data is interval scale with values ranging between $0-100$. The category uses four levels: grades 0-25 with the category "very low", 26-50 with the category "low", 51-75 with category "medium" and 76-100 with the high category.

\section{RESULT AND DISCUSSION}

The assessment of farmers of Strata I and Strata II to the level of the implementation of participatory communication on the empowerment of small farmers is in a low category, with the average of respectively 47.7 and 34.6. The total of farmers perceives low participatory communication with the average score of 45.07. The implementation of participatory communication is the involvement of farmers in dialogue with stakeholders for mutual exchange of information for decisionmaking in stages: the growth of ideas, planning, implementation, and monitoring by considering the ideal situation for dialogue, namely: equality and equal access, independence, and opportunity for open dialogue.

The identification of the program stakeholders consists of outsiders, which are companions, the official organizers of the program and insiders, which are formal and informal leaders as well as village institutions. The rating of farmers of Strata I towards the level of participatory communication or dialogue implementation between farmers and stakeholders (outsider and insider) is low, as seen in the indicators for planning (average score 41.5), implementation (41.3), monitoring and evaluation (47.2) and open debate and arguments (34.9). The description of the aspects of participatory communication implementation level of small farmers' empowerment program is presented in Table 3.

\section{A. Participatory Communication Implementation Level on Growth of Idea Stage}

The assessment of strata I farmers towards the level of participatory communication implementation is high on the growth of ideaindicator (55.8), equality (53.0), and the independence of decision-making (67.2). For strata II farmers, except the indicator of independence, all indicators are low. The total farmers' perception about the involvement in participatory communication on the growth of idea is high (average score of 55.82). Strata II farmers perceive involvement in participatory communication is low (average score of 32.33). All farmers perceive the participatory communication implementation is high (average score of 51.2). This indicates that the implementation of participatory communication (dialogue) between farmers and stakeholders in the growth of idea is included in the high category. The different test result shows highly significant differences between strata I farmers and strata II farmers on the assessment of participatory communication implementation at the growth of idea stage.

Farmers are active and involved in dialogue with stakeholders in the program socialization that starts from the provincial, district, and village levels. At the district level, socialization is attended by the Central Team (IFAD-FAO and Central Food Security Agency) and the Provincial Team, District Team, as well as officials from agencies such as BP4K, Bappeda, BPMD, and Statistics Office. The socialization activity in the village is attended by the organizers of the program from the district, program officer, village head, and village secretary, PPL and informal leaders. Based on the observations and interviews, most farmers are invited to attend the socialization in the village, although not all the community leaders and village institutions (BPD) are present. The socialization is brief and not all farmers' are active in expressing their opinions, but the expectations expressed by some farmers to the program are so the program can: (1) address the small income and dependence on middlemen. (2) help with costly transportation for the marketing of harvested products and access to the garden (3) enhance the expertise to manage the farm.

Farmers determine the poverty criteria, namely: (1) income of less than Rp500.000; (2) send their children only to high school; (3) The house with Katu roof (thatch), walls made of clapboard or half wall and dirt floors; (4) The head of the family do not own their own home; (5) Availability of staples (rice) is not enough in a year/only 9 months; (6) Still do ambulatory cattle and loan system; (7) In order to meet the daily needs still depend on cooperative loans or borrow in the small shop; (8) Crediting motors for motorcycle taxy or motorcycle taxy with other's motorcycle. On the basis of these criteria, the farmers have mutually supervised themselves on who are eligible for the program. Farmers also determine the formation of three groups consisting of 15 households. The formation of the group is conducted by providing funds because based on the previous program experience, the formation of the group conducted shortly after the disbursement of funds, which means the formation of a group is just as a "condition" to "earn" assistance. The formation of the group prior to the disbursement of funds also meant so that the members of the group use the funds in a clear and focused manner. 
Table 3.

The Implementation Level of Participatory Communication on Program Stages and Farmers Strata

\begin{tabular}{|c|c|c|c|c|c|}
\hline $\begin{array}{l}\text { Participatory } \\
\text { Communication on } \\
\text { the Program Stages }\end{array}$ & Category & $\begin{array}{c}\text { Strata I Farmers } \\
\text { (\%) } \\
n=162\end{array}$ & $\begin{array}{l}\text { Strata II Farmers } \\
\qquad \begin{array}{c}(\%) \\
n=40\end{array}\end{array}$ & $\begin{array}{c}\text { Total } \\
(\%) \\
n=202\end{array}$ & $\begin{array}{l}\text { Sig } \\
\text { (Uji t) }\end{array}$ \\
\hline \multirow[t]{5}{*}{ Growth of Idea } & Very Low & 0 & 17 & 3 & $0.000 * *$ \\
\hline & Low & 27 & 83 & 38 & \\
\hline & High & 70 & 0 & 56 & \\
\hline & Very High & 3 & 0 & 2 & \\
\hline & & 55.8 & 32.3 & 51.2 & \\
\hline \multirow[t]{5}{*}{ Planning } & Very Low & 4 & 53 & 14 & $0.000 * *$ \\
\hline & Low & 68 & 47 & 64 & \\
\hline & High & 26 & 0 & 21 & \\
\hline & Very High & 2 & 0 & 1 & \\
\hline & & 41.5 & 23.7 & 38.0 & \\
\hline \multirow[t]{5}{*}{ Implementation } & Very Low & 14 & 30 & 17 & $0.000 * *$ \\
\hline & Low & 54 & 63 & 56 & \\
\hline & High & 28 & 7 & 24 & \\
\hline & Very High & 4 & 0 & 3 & \\
\hline & & 41.3 & 31.1 & 39.3 & \\
\hline Monitoring \& & Very Low & 10 & 17 & 12 & $0.000 * *$ \\
\hline \multirow[t]{4}{*}{ Evaluation } & Low & 36 & 50 & 39 & \\
\hline & High & 46 & 33 & 43 & \\
\hline & Very High & 8 & 0 & 6 & \\
\hline & & 47.2 & 39.5 & 45.7 & \\
\hline \multirow[t]{5}{*}{ Equality } & Very Low & 0 & 0 & 0 & $0.000 * *$ \\
\hline & Low & 36 & 60 & 41 & \\
\hline & High & 63 & 40 & 58 & \\
\hline & Very High & 1 & 0 & 1 & \\
\hline & & 53.0 & 45.6 & 51.5 & \\
\hline \multirow[t]{5}{*}{ Independence } & Very Low & 0 & 0 & 0 & $0.000 * *$ \\
\hline & Low & 3 & 23 & 7 & \\
\hline & High & 77 & 75 & 76 & \\
\hline & Very High & 20 & 2 & 17 & \\
\hline & & 67.2 & 56.6 & 65.1 & \\
\hline \multirow{5}{*}{$\begin{array}{l}\text { Open Debate and } \\
\text { Arguments }\end{array}$} & Very Low & 39 & 43 & 40 & $0.000 * *$ \\
\hline & Low & 37 & 35 & 37 & \\
\hline & High & 23 & 22 & 24 & \\
\hline & Very High & 1 & 0 & 1 & \\
\hline & & 34.9 & 32.1 & 34.4 & \\
\hline
\end{tabular}

Remarks:

$0 \leq 25$ = very low, $26 \leq 50=$ low, $51 \leq 75=$ high, $76-100=$ very high

** $\quad$ Very visible on $\mathrm{p}<0.01$

* Visible on $\mathrm{p}<0.05$

Strata I Farmers = Land $\leq 20.000 \mathrm{~m}^{2}$;

Strata II Farmers $=$ Land $\geq 20.000 \mathrm{~m}^{2}$

\section{B. Level of Participatory Communication Implementation in Planning Stage}

Participatory communication in the planning stage perceived by all the farmers to be relatively low (average score 38.0). Strata I farmers perceive participatory communication in the planning stage in low category (average score 41.5). Strata II farmers perceive participatory communication in the planning stage to be very low (average score 23.7). The different test result shows highly significant differences between the perceptions of strata I farmers and strata II farmers on of the implementation of participatory communication at the planning stage. The overview of the implementation of participatory communication in the planning stages in terms of how is the farmers' response and activity of farmers while involved in 
the program and the process of dialogue between farmers and stakeholders in the planning group.

The response of farmers can be seen from The active participation by attending the planning activities of the group; The involvement of various parties (agents/informal village leaders) together with farmers assessing the business plans of the group; the activeness of farmers to submit proposals and suggestions to the business plan; Cooperation between agents with farmers in preparing the proposed plan; Satisfaction with the results of the group's business plan. At this stage, the attendance of farmers and their active involvement in discussing the group's plans among group members is high. Business plans for each program group in the village include growing food crops (cassava, sweet corn, peanuts, cucumber, and caysin), raising chickens, making cakes, and savings and loan business.

The cause of the low participatory communication at the planning stage is the lack of communication and cooperation between farmers and stakeholders in the planning group activities. The majority of farmers stated that the group discussion to compose the plan involved very lacking external parties (agents and experts). As a result, group activity plan is misdirected. For example, groups of farmers in the Todowongi seek baking only because one of its members is working on the cake. Groups of farmers in Bukumatiti Village choose the business of raising chickens while the characteristics of the area are muddy and marshy, not really supporting the activities of poultry. The lack of dialogue and cooperation between agencies in the planning stages make the farmers difficult to compose plan and proposal of group activities.

\section{Level of Participatory Communication Implementation in Implementation Stage}

The implementation of participatory communication in the implementation phase of the program is perceived low (average score 39.3), strata I farmers and strata II farmers respectively perceive low with the average score of 41.4 and 31.1. There is the really significant difference between the perceptions of strata I farmers and strata II farmers in the implementation of participatory communication. Participatory communication in terms of implementation stage is viewed from response and the activity of farmers in the process of dialogue and cooperation among farmers and between farmers and stakeholders in the implementation stage of the program, including: (1) the activeness of farmers to be involved in carrying out group activities (crop/livestock farming, development of infrastructure to support farming, management of savings and loan activities. And the marketing of group's business products)
(2) the activeness of stakeholders to be involved in group activities, and (3) the opportunity for farmers to have a dialogue with stakeholders to deliver the problems and barriers to activities implementation.

The implementation of participatory communication in the stage of program implementation is low because farmers rarely have a dialogue with stakeholders (officials of the department of agriculture and related SKPD (BP4K, Department of Agriculture and Food Security, BPMD) as well as informal village leaders. Farmers are rarely visited by a companion that causes the farmers to not be actively involved in the program activities. In fact, there are villages that do not carry out any activities until the fiscal year ends. As a result, a group of farmers who raise chickens bearing the loss of mass chicken deaths.

The farmers actively participate in the training of crop and livestock farming techniques, processing of nutmeg syrup, makes tapioca starch, sago, coconut cookies, and chocolate ice cream as well as administration and business management training. Even so, the attendance rate of farmers is low because the training was conducted midDecember where they are busy processing copra and facing the Christmas and New Year. The training is perceived beneficial to farmers, but the training material, especially the innovation on the processing of agricultural products, is not the need of the farmers at the moment, what is needed is a way to process the needed agricultural products and sell in the market. They also need a processing machine for sago and cassava grater along with the training on how to use it. During this time, they use the traditional way, because they can not afford to buy the tools.

\section{Level of Participatory Communication Implementation in Monitoring and Evaluation Stage}

The analysis shows that participatory communication at the stage of monitoring and evaluation is perceived by strata I farmers and strata II farmers to be low with the average score of 47.2 and 39.5 respectively. Based on difference test results, there are visibly significant differences between strata I farmers and strata II farmers on the implementation of participatory communication in program monitoring and evaluation stage.

At this stage, the farmers are involved in group activities together with companions/ extension facilitators, monitoring, and evaluation of programs. Bidirectional communication takes place between the team with the farmers of group members through questions that are evaluative. The team provided the farmers with the opportunity to propose idea and suggestions about things that are still a constraint in the implementation of the program and what 
actions should be taken to overcome the problems and obstacles that arise. However, most farmers did not actively engage in dialogue, only a few administrators who enthusiastically conveyed their concerns and suggestions for the improvements of the program. This is because the administrators have more control of technical matters concerning the administration of the group's financial accounting and group lending activity developments. Proposals and suggestions of farmers were received but not yet acted upon in order to improve the implementation of the program.

\section{E. Ideal Speech Situation}

To observe an ideal speech situation in the discussion conducted by the Program of small farmers empowerment, the author followed and conducted a direct observation of the implementation of the discussion at the village level in the growth of idea stage and discussions at the group level at the planning stage and the implementation of the program. Three fundamental things that become the objects of the author on ideal speech situation are the equality of participants in the dialogue, the independence in decision-making, and the opportunities for farmers to have an open debate about the program with the outsiders.

\section{F. Equality and Equal Access}

The farmers perceive a situation of equality in the discussion at each stage of the program is quite equal (average score of 51.5). The situation of participants equality in the discussion of program stages of the empowerment of small farmers is perceived quite equal by strata I farmers (average score of 53.0), the equality situation perceived by strata II farmers to be less equal (average score of 45.6). Based on the different test, the result is significantly different in the perceptions of participatory communication implementation in the implementation of the program between strata I farmers and strata II farmers.

Discussion on the growth of idea stage, the farmers (men and women) are given an equal opportunity to convey proposals and suggestions. However, not all participants are willing and dare to put forward their proposals or opinions. Some farmers were seen discussing and then telling their colleagues to present the results of the discussion in the forums. When interviewed on why they are reluctant to directly express their opinions and proposals, they stated: "We lacked the courage to speak in front of people because of shame and fear of being wrong ..." This may be because the farmers are still overshadowed by the feeling of less confident in expression at the forum attended by people outside their communities, including organizers of the program, companions, and program officers.
The barriers to talk do not occur because of differences in status and position among the participants because only a handful of village leaders attend the meetings. On the growth of ideas, the discussion participants have full authority in determining farmer households as the beneficiaries of the program, likewise on the group planning discussion, group members discuss to determine their own group activities plan. Barriers to sociocultural values such as gender-based discrimination against the participant do not happen in a situation of discussion, because the participants, both men, and women, express their opinions freely.

At this stage, found the following matters: (1) The attendance of farmers do not meet the target. The discussion which was originally scheduled at 8 am was held at 10 and the audiences were only 36 people (supposedly 45 as District Team selection result in the waiting list as agreed in 2011). The reasons for the absence of farmers is because they are busy in the garden or on the rice harvest in the fields and not all farmers who attended are the head of the family since some farmers are represented by their wives. (2) lack of involvement of village leaders/villagers. Whereas in order to gain support and diverse perspectives, the discussion should be attended by as many as possible elements of the community, either citizens, community leaders and village/districts officials. (3) There is still segregation/separation among the participants (farmers) with agents (companions/fieldworkers) in a discussion forum. Discussion room is set with seating positions as in the classroom, where companions, organizers of the program, village head, and village secretary occupy the front of the room to deal with a group of farmers, the chairman of LPM, and village leaders. In the implementation of discussion, a group of women and men sit in groups and separately. The position of the participants and setting the room thus not fully support the principle of equality in the discussion. This position may reinforce the perception of farmers who considered outsiders have higher social status and position. (4) There is some dominance in the discussion by the chairmen of groups and community leaders in attendance.

At the group level, the dialogue takes place in a situation that makes farmers more open and not hesitated to submit their proposals, suggestions, and opinions. This is due to the proximity of the residence and relationship intimacy between members. However, there are things that require improvement, for example, group discussion held in a living room which of course cannot accommodate all participants of more than ten people. So, there are participants who sit on the porch or in the central part of the house which cause some meeting participants to be less focus on the discussion 
material because limited by the walls and even chat on other topics.

\section{G. Independence in Decision Making}

The study result shows the farmer's perception of the independence to decide on matters related to the needs of groups is in the high category (average score 65.1). Strata I farmers perceive the independence in the decision-making of group decisions is in high category (average score 67.2), as well as strata II farmers (average score 56.6). Based on the different test result, there is a significant difference in perception on the implementation of participatory communication in the implementation of the program between strata I farmers and strata II farmers. These values indicate that farmers in the program of small farmers' empowerment are involved and play an active role in decisionmaking at each stage of the program without any intervention by the other party's interests, both government, and donors.

Although not all farmers have the courage to be open and dare to express their opinion in accordance with the reality that they feel, for example, in determining what are the criteria of poverty, critical attitude in determining who is entitled to receive the program, without the intervention of agents, village leaders or village officials since all this time it is common in the implementation of community empowerment programs. The proposed plan of activities in accordance with the will and needs of farmers through planning meetings at the group level. In other words, the action plan proposed by farmers are not the surrogate of forces or government interests, as often happened in villages. According to farmers, on other planning programs, it is usually taken over by the village officials (head of the village, the village Board of Representatives, Chairman of RW / RT) because they understand the problems of farmers. (3) Farmers also said business group which is currently implemented is in accordance with what has been planned and discussed by members of the group in the meeting.

\section{H. Open Debate and Argument Opportunities}

The opportunity for open debate and arguments in the stages of the program is perceived low by farmers (average score of 34.38). Perception of strata I farmers to the implementation of participatory communication at the stage of monitoring and evaluation is in a low category (average score of 34.94) and likewise for strata II farmers (average score of 32.13). The different test result shows no difference in the assessment of strata I farmers and strata II farmers on the opportunity for open debate and arguments. An important dimension of the ideal speech situation is the opportunity and the ability of farmers to be engaged in open debate to discuss and criticize the program, the program providers, the agents (companion/attendant) and to fellow workshop participants. Including the ability to argue for building a critical attitude of farmers on the program agenda.

But farmers are still afraid to criticize the weaknesses of the program, especially in official meetings. While in fact, a number of problems are often complained by farmers such as loans that are small, the absence of companion in the village to facilitate farmers' groups and only meet the farmers when there is administrative purpose or visit from Central or Provincial Team. Farmers still regard the program as an assistance so that it is not "worthy" to criticize the program. The cause of the low ability of farmers to criticize the program is because of the weak role of mentoring to build awareness and critical attitude of farmers.

\section{CONCLUSION}

The level of participatory communication implementation is included in the low category in the program stages of small farmers' empowerment in aspects of planning, implementation, monitoring, and evaluation. The ideal situation of dialogue is not optimally implemented in small farmers' empowerment program in the aspect of equality, independence, and argumentation. The low implementation of participatory communication as a means of exchanging information between outsider and insider farmers causes the information and knowledge of farmers to be inadequate as a basis for decision-making at the stage of planning, implementing, and evaluating farming activities in the group.

\section{A. Policy Recommendation}

Local Government, particularly the Department of Agriculture correct communication weakness in the implementation of small farmers' empowerment program, through strategy measures:

1) Improving the implementation of participatory communication:

a. Facilitating dialogue and cooperation, such as first, the implementation of a participatory method to build a consensus on the ideal situation so that small farmers can share the experience of their problems and needs. Second, to build participatory communication capacity so that they can participate in dialogue during the process of empowerment.

b. To support the implementation of participatory communication (point a) then the capacity of actors should be improved, namely: (i) companions and officers through training with the material content of dialogue facilitation 
technique (participatory communications) and the empowerment of farmers; (ii) insider which consists of formal leaders (village head and devices) and informal leaders as opinion leader (iii) Farmers as the program participants to be more confident in expressing their opinion through learning to build awareness (conscientization) and the ability of facing problems (problem posing).

c. Quality improvement of the program to bring together farmers and organizers of the program in a dialogue facilitated by companions.

2) The implementation of participatory communication in farmers learning through:

a. Increase the intensity of communication through dialogue "Gathering of Farmers' and group meetings as well as become the place of learning together.

b. Integrating interpersonal communication channels and media as a learning tool for farmers and customize the learning material to the needs of farmers.

c. Developing varied learning methods, including demonstrations (means and demonstration plots, field schools, internships, and group visits.

\section{B. Theoretical Implication}

The study result shows that the level of farmer participation and participatory communication implementation in the empowerment of small farmers are relatively low in the planning, implementation, monitoring, and evaluation stages as well as the unmet dialogue ideal situation at the stages of Small Farmer Empowerment Program.

The finding confirms the statements of Pretty (1995), Mefalopulos (2003), and Ascroftand Masilela (2004), that communication and participation are important components in development practices and highly appreciated on paper but poor in the application. Often time, development programs are with the participatory label but the involvement of outsiders with the community is very limited, while communication (dialogue) is only regarded as an additional component and has not been used as a strategic tool, so it loses its effectiveness.

The concept of participation has been adopted in the implementation of the empowerment of small farmers, but the understanding and application of the concept of participation are not appropriate if observed from the lack of involvement from the outsiders (companion, organizers of the program and technical officers) in the implementation of the program. In this case, participation is interpreted by the program organizers and companions that all activities at the stages of the program (planning, implementation, and monitoring) are delivered to farmers without any communicative intervention in the form of cooperation and dialogue to share knowledge, experience, and skills. In the case of independent farmers, it is possible but it can not be justified in the case of small farmers with the minimal ability to farm and low access to development resources. Referring to the opinion of Freire (1970), Thomas (2004), Nair and White (2004) who interpret participation as a collective action and open dialogue among stakeholders in the development, then communicative intervention between outsiders (companion, organizers of the program, technical officers) and insiders (village leaders and social institutions) with small farmers is needed in the process of small farmers empowerment. Cooperation and dialogue to share information between small farmers with outsiders and insiders become an important part to address problems faced by farmers and as a basis for farming decision making.

The role of companions and technical officers is weak in facilitating farmers in planning, implementation, up to monitoring and evaluation stages. When the group encounter problems or obstacles in running their business, the board (chairman) take the initiative to gather members for discussion to find solutions. The board meet organizers of the program (Department of Agriculture and Foodcrop) only when there are problems related to administration of the program, financial, or assistance to farmers. Referring to the participatory model according to Nair and White (2004), a situation in which the program receivers tend to be active while the outsiders, especially companion and program providers (communicator development) are passive, as described above, then the typology of participation from the behavioral perspective of development communicator and the recipient are in the Bottom-up typology (high intended receiver and low development communicator), the description is presented in Figure 2.

The result of the study also confirms the opinion of Freire (1970/2000) that the praxis of local participation, the especially dialogue in development program is an important part of the process of empowerment and awareness creation of program participants to their reality. Participatory empowerment of small farmers have not been implemented on the program and it is identified with the weak intensity of interaction and two-way communication between outsider and insider with small farmers. Whereas the original (authentic) participation can allow community members to engage in the dialogic meeting to express their own reality. Through dialogue, people can obtain critical consciousness (critical conscientization) against the problems and realities and start looking for a solution model. This means that if the development 
is intended for the benefit of the poor in rural areas, then their participation is really crucial in the development process. Freire and Faundez (1995) agreed that "Intellectuals (companion, experts/ researchers, bureaucracy, and organizers of the program) should find that their critical faculties are not worth more or less valuable than the sensitivity of people in need, both are equally necessary to understand the reality". Correspondingly, Servaes (2002) suggested the implementation of grass root dialogue forum for the participation in decisionmaking at the community level by bringing together resources and agents of change directly to citizens by using dialog for awareness method (conscientization).

The rationality of the importance of development dialogue is because the knowledge of agencies (government bureaucracy, facilitators, and expert), although valid, is not sufficient in solving local problems. They need to learn and have a dialogue with the people (farmers) who have local knowledge (indigenous intellectual) (White, 2004; Cummins \& Conventry 2009). Dialogue as a solution to the gap between the providers of the program (government, donors) to farmers is based on: first, the farming community is not an empty space with no value and will that can be filled with any program, and, likewise, the government or donor agencies are not free of interest, so they could reciprocally clash and negate. Second, between farmers and the government or between government agencies have a variety of perspectives on needs that can be conflicting, and even the willingness of farmers could rub against the village elite who lead them. As a result, farmers often reject development program either overtly or covertly in the form of low participation or indifference

Dialog negates one direction information from the top or from the outside but uses the communicative nature to exchange knowledge, investigate problems and opportunities, and ultimately reach a consensus about the intended change among all stakeholders. The involvement of small farmers can overcome their alienation situation in the development process. Development is more humane because it puts the citizens in a more decent and dignified manner, thus the residents are the owners of the development. Freire (1984) firmly rejected the alienation of beneficiaries in the empowerment program, he said: "one is not intact when he lost the ability to choose when the choice is the choice of others, and if the decision comes from the outside, then it is not his own decision". A whole human being is a human being as a subject, while human who is adapting is human as an object. Therefore, adaptation is a form of most vulnerable self-defense, someone adapts because he is unable to change the reality.

Government intervention creates important empowerment of small farmers, but without negating the application of participatory method and dialogue in the process of empowerment. In a structural perspective, according to Nasdian (2007), the factors which impede the empowerment of lower layers of society need to be observed. Often, empowerment is actualized notbecause of structural issues in which lower communities are powerless to deal with the interests of the stronger side. Additionally, oversight, monitoring and evaluation mechanism and inter-agency coordination are not yet working as they should. In order to avoid the domination of the structure (the dominance of central government bureaucracy down to the village and elite), then dialogue and the creation of dialogue ideal situation can ensure the participation of farmers in an authentic manner in defining the problems and needs, finding an alternative solution, up to planning and implementing the agreed plan together.

Starting from the ideal situation, the dialogue

DEVELOPMENT COMMUNICATOR

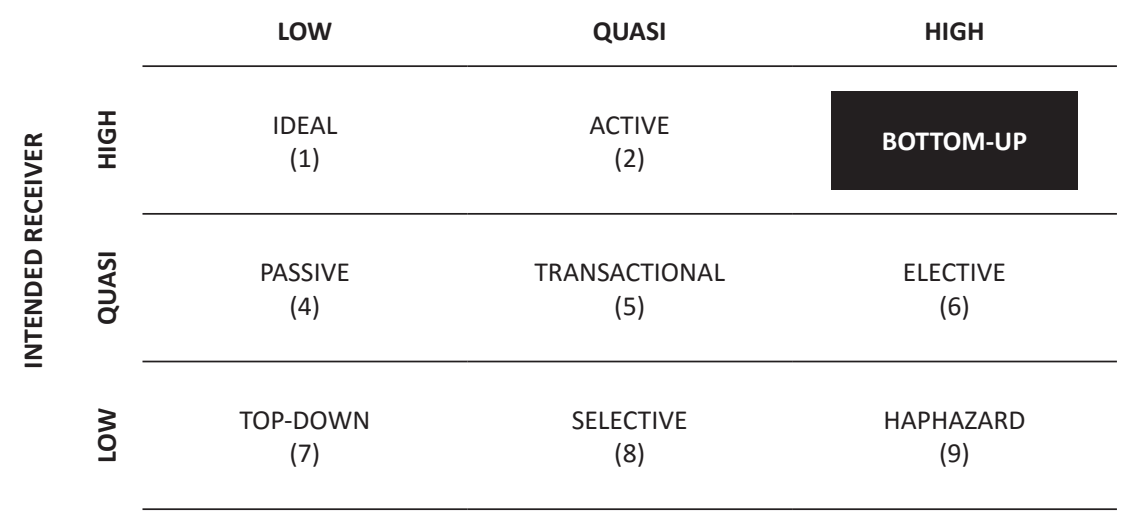

Figure 2. Typology of Participation from Behavioral Perspective of Development Communicators and Receivers 
which is held in the program must ensure that: (1) Each participant (outsider, insider and farmers) have similar position to argue on a reciprocal basis; (2) Decision of the program participants are free from domination of the elite, and (3) There is an opportunity for open debate and arguments to criticize the program. But the facts in the field prove that the ideal speech situation in the dialogue as proposed by Habermas is difficult to happen in our society. The condition of socioeconomic status (mainly income and education) often makes them reluctant to have a dialogue on an equal footing and argumentative with the power structures (bureaucracy) or village elites. Residents (farmers) often put themselves in the position of "weak" and consider the outsiders (experts, bureaucracy organizers, and village elites) to be "higher" and "influential" than themselves. This perception affects the low confidence to perform equally in expressing their opinions, engage and influence decision-making and criticize the programs (government). This is a proof that the application of Habermas's concept of ideal speech situation is not always easy to apply in situations which precisely a relation system of "patron" and "client".

Increased empowerment of small farmers needs a communicative intervention in the learning process of farmers through extension services. Freire (1969) stated that the practice of agricultural extension should avoid an ideology with the structure that is hierarchical, vertical, controls and one direction connection from the extension agents or officials to small farmers who are basically not participatory. The learning objective of the farmers is not to "fill" the farmer with the "knowledge", both technical and a number of information in the concept of banking education style (Banking Concept Education), but to create a social system of farmers who are critical of the issues they face and able to analyze their own situations and in the end assist them in planning their farming.

Extension approach that characterizes linear communication in the form of information dissemination and innovation or technology transfer is not suitable to facilitate the learning of farmers (Biggs and Farrington in Lubis 2007; Cummnis and Convetri (2009); Winarto (2012). The model of innovation and transfer of technology adoption which is characterized by linear communication is not appropriate to facilitate the learning process of farmers because (1) it ignores the system of research and informal development undertaken by farmers. This model also ignores a suitability between the technology delivered with the opportunities and constraints of the farmers; (2) the transfer of technology and the diffusion of innovation, inherently, is centralized, so it is unable to take into account the diversity of agroecology, insensitive to feedback to the sustainability of the technology and not pay attention to technology implementation capacity.

\section{REFERENCES}

Anyaegbunam, C., Mefalopulos, P., \& Moetsabi, T. (2004). Participatory Rural Communication Appraisal: Starting with the People. Rome: Food and Agriculture Organization of the United Nations.

Ascroft, J. \& Masilela, S. (2004). Participatory Decision Making in Third World Development. In S. White, Participatory Communication: Working for Change and Development. New Delhi: Sage Publications.

Belbase, S. (2004). Participatory Communication for Development. In S. White, Participatory Communication: Working for Change and Development. New Delhi: Sage Publications.

Chambers, R. (1983). Rural Development: Putting the Last First. Harlow: Prentice Hall.

Chambers, R. (1997). Whose Reality Counts? Putting the First Last. London: Intermediate Technology.

Chang, L. (2006). Measuring Participation: a Secondary Data Analysis. Presentation, Dresden International Congress Centre, Dresden, Germany.

Chitnis, K. (2011). Recasting the Process of Participatory Communication through Freirean Praxis: the Case of the Comprehensive Rural Health Project in Jamkhed, India. Presentation, International Communication Association, Sheraton New York, New York City.

Cummins, J. (2009). Enhancing the Adoption of Conservation Farming System in Three Countries of Contrast: Eritrea, India and Australia. Presentation, International Conference on Agricultural Extension.

Freire, P. (1969). Education for Critical Consciousness. New York: The Seabury Press.

Freire, P. (1970). Pedagogy of the Oppressed. New York: Continuum.

Freire, P. (1984). Pendidikan Sebagai Praktek Pembebasan (Terj.). Jakarta: PT. Gramedia.

Freire, P. (2000). Pendidikan Kaum Tertindas (Terj.). Jakarta: LP3ES.

Habermas, J. (1990). Moral Consciousness and Communicative Action. Cambridge, Mass.: MIT Press.

Habermas, J. (1996). The Theory of Communicative Action: Reason and the Rationalization of Society. Boston: Beacon Press.

Jacobson, T. \& Storey, J. (2004). Development Communication and Participation: Applying Habermas to a Case Study of Population Programs in Nepal. Communication 
Theory, 14(2), 99-121. http://dx.doi. org/10.1111/j.1468-2885.2004.tb00307.x

Kountur, R. (2006). Metode Penelitian untuk Penulisan Skripsi dan Tesis. Jakarta: PPM.

Leeuwis, C. (2009). Komunikasi untuk Inovasi Pedesaan: Berpikir Kembali tentang Penyuluhan Pertanian. Jakarta: Kanisius.

McPhail, T. (2009). Introduction to Development Communication. Development Communication, 1-20. http://dx.doi. org/10.1002/9781444310740.ch1

Mefalopulos, P. (2003). Theory and Practice of Participatory Communication: the Case of the FAO Project "Communication for Development in Southern Africa" (Dissertation). The University of Texas at Austin.

Mefalopulos, P. (2005). Empowerment Communication. In A. Gumucio-Dagron \& T. Tufte, Anthology: Historical and Contemporary Readings. New Jersey: Communication for Social Change Consortium.

Melkote, S. (1991). Communication for Development in the Third World: Theory and Practice. New Delhi: Sage Publications.

Mosse, D. (2004). 'People's Knowledge', Participation and Patronage: Operations and Representations in Rural Development. In B. Cooke \& U. Kothari, Participation: The New Tyranny? London: Zed Books.

Nasdian, F. (2007). Pemberdayaan Masyarakat Berbasis Ekologi dalam Ekologi Manusia. Bogor: Institut Pertanian Bogor.

Pretty, J. (1995). Regenerating Agriculture: Policies and Practice for Sustainability and Self-reliance. London: Earthscan Publication Ltd.

Priastana, J. (1998). Teori Tindakan Komunikasi Habermas Sebagai Titik Pijak Dialog Antar Agama (Master Thesis). Universitas Indonesia.

Sajogjo,. (1999). Menuju Program Partisipatif dan Berkelanjutan (Belajar dari Program PDMDKE). Kerja sama Pusat P3R dan Pemda Jawa Barat.

Satriani, I., Muljono, P., \& Lumintang, R. (2011). Komunikasi Partisipatif pada Program Pos Pemberdayaan Keluarga. Jurnal Komunikasi Pembangunan, 9(2), 17-27.

Servaes, J. (2002). Communication for Development: One World, Multiple Cultures. New Jersey: Hampton Press.

Servaes, J. (2005). Mapping the New Field of Communication for Development and Social Change. Presentation, Social Change in the 21st Century Conference, 28 October 2005, QUT, Brisbane.

Servaes, J. (2007). Harnessing the UN System Into a Common Approach on Communication for Development. International Communication Gazette, 69(6), 483-507. http://dx.doi. org/10.1177/1748048507082838

Sumardjo,. (1999). Transformasi Model Penyuluhan Pertanian Menuju Pengembangan Kemandirian Petani (Kasus di Propinsi Jawa Barat) (Dissertation). Institut Pertanian Bogor.

Wolf, E. (1985). Petani Suatu Tinnjauan Antropologis. Jakarta: CV. Rajawali. 